\title{
Effect of Cytokinins on Multiple Shoot Regeneration from Leaf Derived Callus of Inula royleana DC.
}

\author{
Samar Amin*, Zahoor A Kaloo and Seema Singh \\ Plant Tissue Culture Research Laboratory, Department of Botany, Faculty of Biological \\ Sciences, University of Kashmir, Hazratbal, Srinagar, JEK, India
}

Key words: Effect of cytokinins, Inula royleana, Multiple shoot regeneration

\begin{abstract}
Effects of cytokinins were studied on multiple shoot regeneration in Inula royleana DC. Callus from leaf of $I$. royleana was treated with different concentrations of BAP and in order to find out the limiting concentrations of both $\mathrm{BAP}$ and $\mathrm{Kn}$ at which maximum shoot regeneration took place. Among different concentrations $1 \mathrm{mg} / \mathrm{l} \mathrm{BAP}$ and $0.8 \mathrm{mg} / \mathrm{l} \mathrm{Kn}$ proved to be optimum. Rooting was obtained in White's medium. Regenerated plantlets were successfully acclimatized in pots containing vermicompost.
\end{abstract}

\section{Introduction}

Cytokinins influence a number of plant developmental processes, viz., cell expansion, inhibition of leaf senescence, chloroplast development, mobilization of nutrients, and root and shoot branching. Skoog and Miller (1957) besides realised that it is the ratio of cytokinin to auxin in nutrient media which affect the shoot and root regeneration. Jouanneau $(1970,1975)$ suggested the role of cytokinins in regulating the synthesis of proteins that helps the formation and function of mitotic spindle apparatus. It was further observed that in cultures where cytokinin is limiting, division of cell nuclei becomes arrested at one stage of the cell cycle and the course starts again only when the tissue was subcultured on a medium adjuvanted by a cytokinin (Jouanneau 1971). Some callus tissues like that of Oxalis dispar divide without the addition of cytokinin to the culture medium (Sunderland and Wells 1968), suggesting the presence of natural growth substances in the tissues. Cytokinins are very effective in promoting

*Author for correspondence: <samarbot@gmail.com>. 
direct or indirect shoot initiation. Paterson and Rost (1981) found that addition of cytokinin to the medium induces shoot regeneration from a superficial meristem, and roots were afterwards produced from inside the callus. Keeping these properties of cytokinins in view, during present study, cytokinins viz., BAP and $\mathrm{Kn}$ were used to induce multiple shoot regeneration from leaf derived callus of Inula royleana DC., which can ultimately lead to conservation of this plant species by producing large number of plants in minimum time and space. To our knowledge, this is the first study where limiting concentrations of BAP and $\mathrm{Kn}$ has been worked out in this plant.

\section{Materials and Methods}

Leaf explants were first surface sterilized using Labolene and Tween-20. Sodium hypochlorite $(2 \%)$ was also used for $8 \mathrm{~min}$. The sterilized explants were inoculated in vials containing MS, $3 \%$ sucrose and $0.8 \%$ agar and supplemented with $0.5,0.8,1,2,3$ and $4 \mathrm{mg} / \mathrm{l} \mathrm{BAP}$. The $\mathrm{pH}$ of medium was 5.8. The cultures were incubated at $22 \pm 4^{\circ} \mathrm{C} ; 18 \mathrm{hrs}$ photoperiod. Callus from leaf was subcultured on MS supplemented either with $0.5,0.8,1,2,3,4$ and $5 \mathrm{mg} / 1$ BAP or 0.5, $0.8,1,2,3$ and $4 \mathrm{mg} / \mathrm{l} \mathrm{Kn}$. Once shoots start appearing, mean number of shoots, mean shoot length $(\mathrm{cm})$, mean number of days taken for shoot regeneration and per cent culture response were recorded. MS containing IAA, NAA and IBA at different concentrations was used for root regeneration but the frequency and response was very low. Another problem encountered was callusing at the base of the shoots and then rooting from callus. However, successful rooting was obtained on White's basal medium (White 1963). The basal portion of roots of in vitro regenerated plantlets was thoroughly washed with double distilled water. These were then planted in pots containing vermicompost. These pots were transferred to pot house and watered after every 2 days. The experiments were repeated thrice and effects of different treatments were quantified. The data were analysed through SPSS 16 and significance was tested using DMRT.

\section{Results and Discussion}

Percentage of callus induction and amount of callus per explant were significantly influenced by BAP. Amount of callus and per cent culture response increased while increasing the concentration of $\mathrm{BAP}$, reached maximum when BAP was supplemented at a concentration of $2 \mathrm{mg} / \mathrm{l}$. Further increase in BAP concentration decreased the amount as well as percentage of callus induction (Fig. 1). Our results are in accordance with that of Sivanesan and Jeong (2007) who induced callus from leaf explants of Pentanema indicum on MS adjuvanted with BAP individually. 
Shoot regeneration was found to be greatly influenced by addition of BAP and $\mathrm{Kn}$ individually at different concentrations to the medium. An increase in the concentration of BAP from 0.5 to $5 \mathrm{mg} / \mathrm{l}$ and $\mathrm{Kn}$ from 0.5 to $4 \mathrm{mg} / \mathrm{l}$ resulted in proportional increase in the number of shoots regenerated but a further increase in cytokinin concentration resulted in the decreased number of regenerated shoots (Table 1, Fig. 2a,b).Our results are in accordance with the study of Ferreira and Handroo (1988) who obtained shoot regeneration from leaf explants of Stevia rebaudiana on $\mathrm{MS}$ supplemented with $\mathrm{BAP}$ alone.

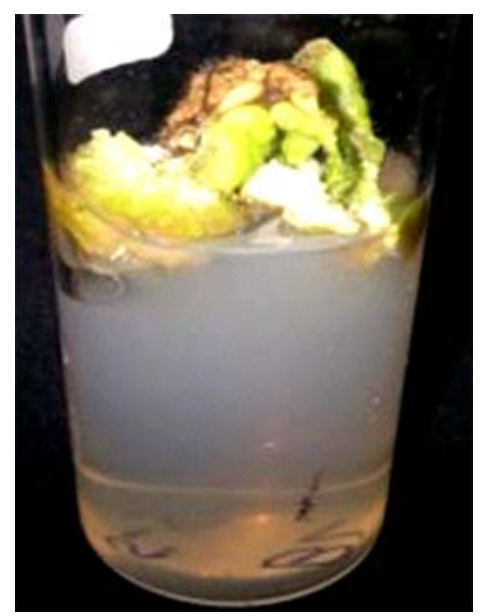

Fig. 1. Callus induction from leaf explant of I. royleana on MS containing $2 \mathrm{mg} / \mathrm{l}$ BAP.
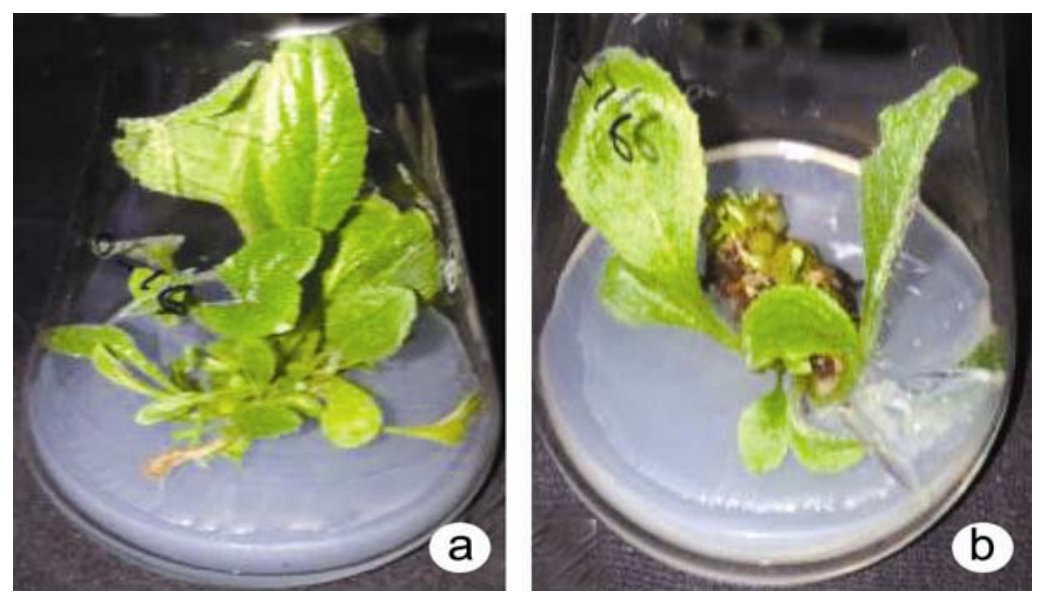

Fig. 2. Multiple shoot induction from leaf derived callus on MS containing: a, BAP $1 \mathrm{mg} / \mathrm{l}$ and b. Kn $0.8 \mathrm{mg} / \mathrm{l}$

MS supplemented IBA $(0.8 \mathrm{mg} / \mathrm{l})$ was effective in inducing roots. However, frequency of regeneration was very low. Thus, rooting medium was changed to 
White's medium which proved to be best as 4 mean number of roots with mean root length of $3.17 \mathrm{~cm}$ within 32 days with $90 \%$ culture response that too without any growth regulator (Fig. 3). There are no reports of use of White's medium for inducing root regeneration in any medicinal plant of Asteraceae family.

Table 1. Effect MS of different concentrations of BAP and $\mathrm{Kn}$ on indirect shoot regeneration from leaf derived callus.

\begin{tabular}{cccccc}
\hline $\begin{array}{c}\text { BAP } \\
(\mathrm{mg} / \mathrm{l})\end{array}$ & $\begin{array}{c}\text { Kn } \\
(\mathrm{mg} / \mathrm{l})\end{array}$ & $\begin{array}{c}\text { Mean } \\
\text { number of } \\
\text { shoots }\end{array}$ & $\begin{array}{c}\text { Mean shoot } \\
\text { length } \\
(\mathrm{cm})\end{array}$ & $\begin{array}{c}\text { Mean number of days } \\
\text { taken for shoot } \\
\text { regeneration }\end{array}$ & $\begin{array}{c}\text { Per cent } \\
\text { culture } \\
\text { response }\end{array}$ \\
\hline 0.5 & - & $4.4^{\mathrm{d}}$ & $3.4^{\mathrm{a}}$ & 43 & $50^{\mathrm{c}}$ \\
0.8 & - & $8.3^{\mathrm{c}}$ & $3.3^{\mathrm{a}}$ & 41 & $60^{\mathrm{bc}}$ \\
1 & - & $33.5^{\mathrm{a}}$ & $3.4^{\mathrm{a}}$ & 23 & $80^{\mathrm{a}}$ \\
2 & - & $16^{\mathrm{b}}$ & $2.8^{\mathrm{b}}$ & 24 & $70^{\mathrm{ab}}$ \\
3 & - & $10^{\mathrm{c}}$ & $3.7^{\mathrm{a}}$ & 35 & $70^{\mathrm{ab}}$ \\
4 & - & $8.6^{\mathrm{c}}$ & $2.2^{\mathrm{c}}$ & 37 & $50^{\mathrm{c}}$ \\
5 & - & $4.8^{\mathrm{d}}$ & $3.4^{\mathrm{a}}$ & 37 & $50^{\mathrm{c}}$ \\
- & 0.5 & $3.3^{\mathrm{e}}$ & $4.2^{\mathrm{ab}}$ & 39 & $40^{\mathrm{ab}}$ \\
- & 0.8 & $12.8^{\mathrm{a}}$ & $3.7^{\mathrm{bc}}$ & 37 & $50^{\mathrm{a}}$ \\
- & 1 & $9.6^{\mathrm{b}}$ & $3.8^{\mathrm{abc}}$ & 40 & $50^{\mathrm{a}}$ \\
- & 2 & $7.8^{\mathrm{c}}$ & $3.5^{\mathrm{bc}}$ & 43 & $40^{\mathrm{ab}}$ \\
- & 3 & $5.8^{\mathrm{d}}$ & $4.5^{\mathrm{a}}$ & 43 & $40^{\mathrm{ab}}$ \\
- & 4 & $5^{\mathrm{d}}$ & $3.4^{\mathrm{c}}$ & 47 & $30^{\mathrm{b}}$ \\
\hline
\end{tabular}

Ten replicates per treatment. The significance was tested by DMRT. The values with the same alphabet are non-significant with respect to each other. Different alphabets represent significance at $\mathrm{p}=0.05)$.

Plants with fully-expanded leaf and vigorously growing roots were hardened against humidity and mode of nutrition. Finally, they were transplanted to pots containing vermicompost. Most of plants survived after transferring to pot house for almost 3 months and the survival rate was $>90 \%$ (Fig. 4a-d). The plant regeneration protocol was accomplished within 3 months of culture (27 days of callusing, 23 days of shooting and 32 days of rooting). 


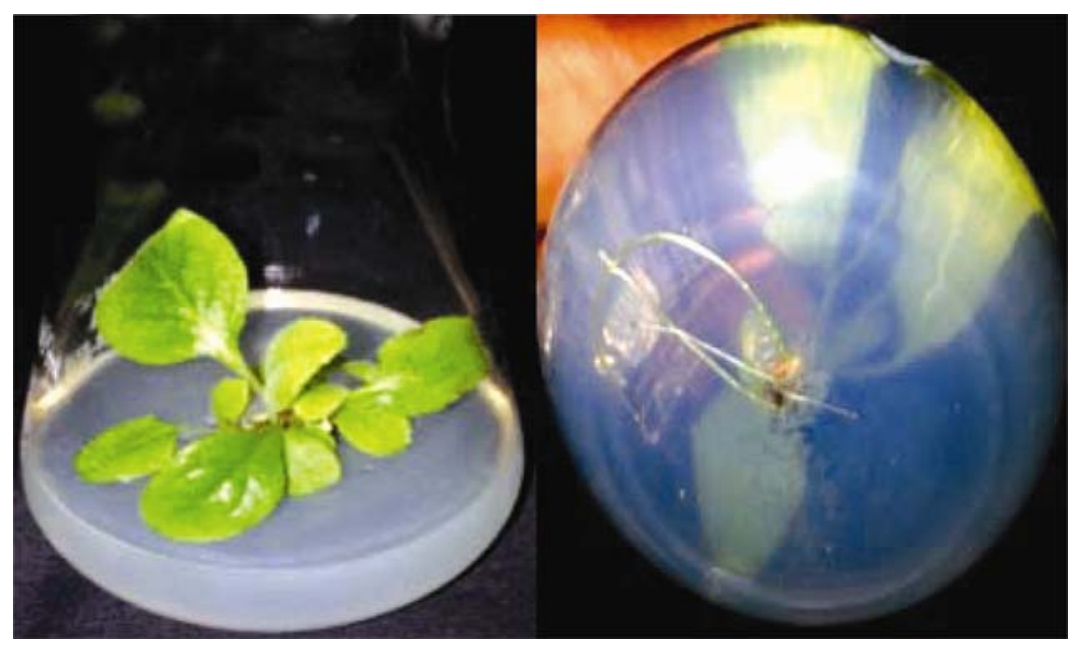

Fig. 3. Root regeneration on White's medium.
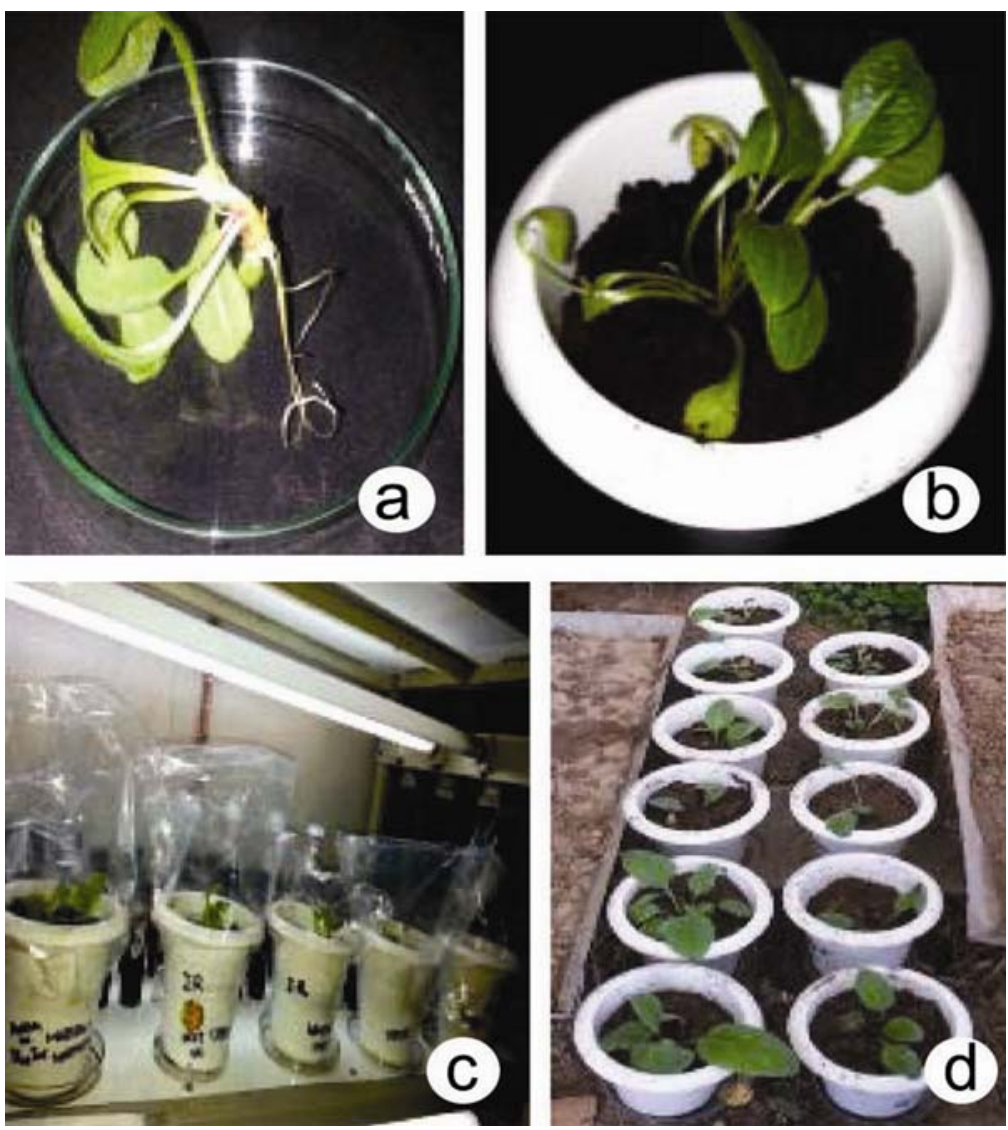

Fig. 4. Steps involved while acclimating the in vitro regenerated plantlets. 


\section{Acknowledgement}

Authors are highly thankful to UGC for providing financial assistance in the form of MRP project.

\section{References}

Ferreira CM and Handroo W (1988) Micropropagation of Stevia rebaudiana through leaf explants from adult plants. Planta Medica. 54: 157-160.

Jouanneau JP (1970) Renouvellement des protéines et effetspécifique de la kinétinesur des cultures de cellules de Tabac. Physiol. Plant. 23: 232-244.

Jouanneau JP (1971)Côntrole par les cytokinines de la synchronisation des mitoses dans les cellules de tabac. Exp. Cell Res. 67: 329-337.

Jouanneau JP (1975) Protein synthesis requirement for the cytokinin effect upon tobacco cell division. Exp. Cell Res. 91: 184-190.

Miller CO and Skoog F (1957) Chemicalregulation of growth and organ formation inplant tissue culturesin vitro. Symp. Soc. Exp. Biol. 11: 118-131.

Paterson KE and Rost TL (1981) Callus formation and organogenesis from cultured leaf segments of Crassula argentea: cytokinin-induced developmental pattern changes. Amer. J. Bot. 68: 965-972.

Sivanesan L and Jeong BR (2007) Micropropagation and in vitro flowering in Pentanema indicum Ling. Plant Biotechnology. 24: 527-532.

White PR (1963) The cultivation of animal and plant cells, 2nd eds, Ronald Press, New York. 